\title{
Metals in some dominant vascular plants, mosses, lichens, algae, and the biological soil crust in various types of terrestrial tundra, SW Spitsbergen, Norway
}

\author{
B. Wojtuń • A. Samecka-Cymerman • \\ K. Kolon • A. J. Kempers · G. Skrzypek
}

Received: 10 January 2013/Revised: 10 August 2013/Accepted: 12 August 2013/Published online: 29 August 2013

(C) The Author(s) 2013. This article is published with open access at Springerlink.com

\begin{abstract}
Arctic environments are commonly considered to be relatively pristine because of minimal local human activity. However, these areas receive air pollution from lower latitude regions. Our goal was to determine concentrations of metals $(\mathrm{Cd}, \mathrm{Co}, \mathrm{Cr}, \mathrm{Cu}, \mathrm{Fe}, \mathrm{Hg}, \mathrm{Mn}, \mathrm{Ni}, \mathrm{Pb}$, and $\mathrm{Zn}$ ) in dominant species of vascular plants, mosses, lichens, algae, and in the biological soil crust (BSC), and topsoil $(0-3 \mathrm{~cm})$ from various types of tundra in the southwestern part of Spitsbergen, Norway. Results indicate that mosses are more efficient bioaccumulators of $\mathrm{Cd}, \mathrm{Co}$, $\mathrm{Cr}, \mathrm{Cu}, \mathrm{Fe}, \mathrm{Mn}$, and $\mathrm{Zn}$ than lichens. The highest levels of $\mathrm{Co}, \mathrm{Cr}, \mathrm{Cu}, \mathrm{Fe}, \mathrm{Hg}, \mathrm{Mn}, \mathrm{Ni}$, and $\mathrm{Pb}$ were found in the $\mathrm{BSC}$,
\end{abstract}

Electronic supplementary material The online version of this article (doi:10.1007/s00300-013-1399-0) contains supplementary material, which is available to authorized users.

B. Wojtuń · A. Samecka-Cymerman $(\bowtie) \cdot$ K. Kolon Department of Ecology, Biogeochemistry and Environmental Protection, Institute of Botany, Wrocław University, ul. Kanonia 6/8, 50-328 Wrocław, Poland

e-mail: sameckaa@biol.uni.wroc.pl

B. Wojtuń

e-mail: bronislaw.wojtun@biol.uni.wroc.pl

K. Kolon

e-mail: kolonk@biol.uni.wroc.pl

\section{A. J. Kempers}

Department of Environmental Sciences, Radboud University, Huygens Building, Heijendaalseweg 135, 6525 AJ Nijmegen, The Netherlands

e-mail: L.Kempers@ science.ru.nl

\section{G. Skrzypek}

West Australian Biogeochemistry Centre, John de Laeter Centre of Mass Spectrometry, School of Plant Biology, The University of Western Australia, MO90, 35 Stirling Highway, Crawley, WA 6009, Australia

e-mail: grzegorz.skrzypek@uwa.edu.au and the moss species Racomitrium lanuginosum, Sanionia uncinata, and Straminergon stramineum from the polygonal tundra, initial cyanobacteria-moss wet tundra, snow bed cyanobacteria-moss tundra, and flow water moss tundra alimented by melting ice or snow. The observed higher concentrations of $\mathrm{Cu}$ and lower concentrations of $\mathrm{Hg}$ in mosses, lichens, and vascular plants compared with values observed 20 years earlier were apparently associated with changes in the atmospheric deposition of contaminants over Spitsbergen due to changes in the long-distance transport of anthropogenic emissions from industrialized areas. Prasiola crispa and Salix polaris may be useful bioindicators of $\mathrm{Cd}$ and $\mathrm{Zn}$, and the BSC, R. lanuginosum, $S$. uncinata, and $S$. stramineum as bioindicators of $\mathrm{Co}, \mathrm{Cr}$, $\mathrm{Cu}, \mathrm{Fe}, \mathrm{Hg}, \mathrm{Mn}, \mathrm{Ni}$, and $\mathrm{Pb}$. These results may be extrapolated across other areas of Spitsbergen with similar climates.

Keywords Arctic - Svalbard - Anthropogenic emissions $\cdot$ Bioindication $\cdot$ Long-distance transport

\section{Introduction}

Arctic environments are commonly considered to be relatively pristine and stable because of the absence of intensive local human activities and of significant local atmospheric contamination sources. However, these areas receive air pollution from lower latitude regions (Headley 1996; Bard 1999; Simões and Zagorodnov 2001). Especially in the northern hemisphere, where anthropogenic sources are concentrated in Europe, North America, and Siberia, the natural cycles are strongly influenced by anthropogenic emissions containing toxic elements (Savinov et al. 2003). Ecosystems in the Arctic are highly sensitive to human 
impacts. Because of relatively simple food webs, even a minor amount of contamination can exert extensive impacts throughout the ecosystem (Gulińska et al. 2003). Svalbard is a unique area in Europe where local atmospheric pollution sources are very restricted. It is far removed from major sources of atmospheric pollution but is recognized to be one of the areas most affected by anthropogenic pollution transported from industrialized areas (Drbal et al. 1992; Birks et al. 2004). These high pollutant concentrations result from specific atmospheric circulation patterns, which bring emissions from oil and coal combustion, non-ferrous metal production, and other sources of anthropogenic pollutants from Europe to Svalbard. Several studies have shown that the atmosphere over Svalbard during winter is heavily loaded with a variety of anthropogenic pollutants, including metals (Heintzenberg et al. 1981; Simões and Zagorodnov 2001). There have also been some indications that polluted air reaches this area during summer (Heintzenberg et al. 1991). Another study demonstrated that contamination of Arctic air led to the bioaccumulation of metals in each trophic level, including terrestrial biota (Xie et al. 2006). Bryophytes, as well as lichen and algae, are abundant in the Arctic, particularly in the wet and low tundra (Smith 1982). They live in ecosystems considered to be extremely severe because of low temperatures, low nutrient availability, and a short growing season; hence, abiotic factors are supposed to be largely responsible for the restrictions imposed upon the distribution of populations (Davey 1997; Hoshino et al. 1999). The aim of this study was to investigate the level of metal contaminants $(\mathrm{Cd}, \mathrm{Co}, \mathrm{Cr} \mathrm{Cu}, \mathrm{Fe}, \mathrm{Hg}, \mathrm{Mn}, \mathrm{Ni}, \mathrm{Pb}$, and
$\mathrm{Zn}$ ) in dominant higher plants, mosses, lichens, algae, and the BSC collected from various types of terrestrial tundra in the southwestern part of Spitsbergen. We tested the hypothesis that terrestrial mosses are the best bioindicators of contamination in comparison with other plant species, lichens, algae, and the BSC in the various types of the terrestrial tundra.

\section{Materials and methods}

Sampling design

The study site was conducted in the southwestern area of Spitsbergen on Wedel Jarlsberg Land, on the northwest side of Hornsund fjord, in the vicinity of the Polish Polar Station $\left(77^{\circ} 00^{\prime} \mathrm{N} ; 15^{\circ} 33^{\prime} \mathrm{E}\right)$, and investigated during the summer of 2011 (Fig. 1). The region is a typical Arctic tundra ecosystem and is located in the Fuglebekken catchment area. A total of 35 sites were selected (Fig. 1) representing ten types of tundra (Table 1) modified based on Kuc (1998) and Szymański et al. (2013). According to Walker et al. (2005), Svalbard belongs to a bioclimatc subzone of the Arctic, and this part of Spitsbergen is classified as a physiognomic category of sedge/grass moss wetland. We collected vascular plants: Cerastium arcticum, Cochlearia groenlandica, Poa alpina, Salix polaris, and Saxifraga oppositifolia; mosses: Aulacomnium palustre, Bryum pseudotriquetrum, Plagiomnium ellipticum, Racomitrium lanuginosum, Sanionia uncinata, Straminergon stramineum, Tetraplodon

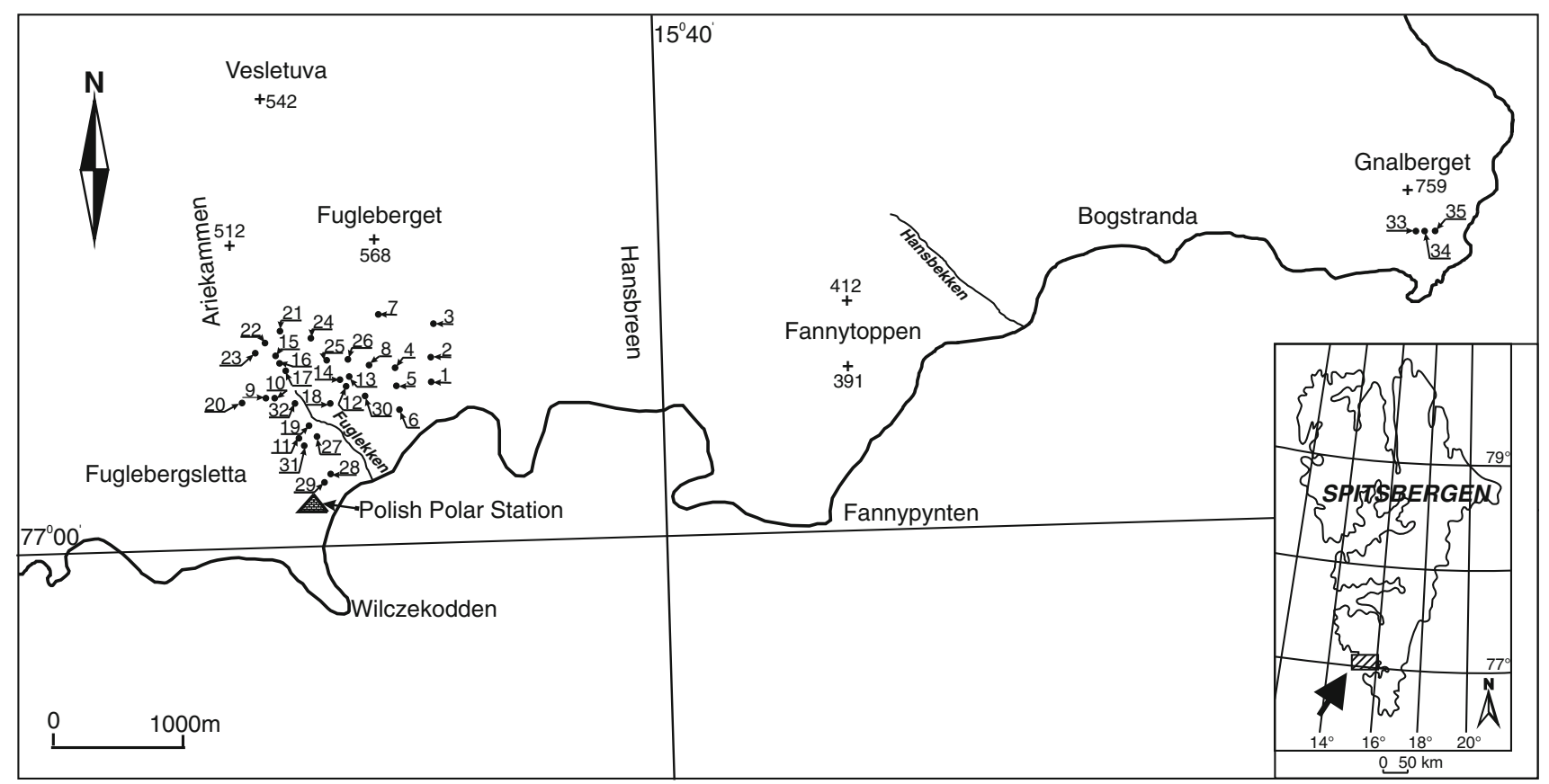

Fig. 1 Map showing study areas and sampling locations 
Table 1 Type of tundra and number of species collected from sampling sites

\begin{tabular}{|c|c|c|}
\hline Type of tundra (sites) & Habitat characterization & Species ( $N$-number of samples) \\
\hline Geophytic initial dry tundra (1-3) & Dry sites on lateral moraine & $\begin{array}{l}\text { Saxifraga oppositifolia }(N=15), \text { Racomitrium } \\
\text { lanuginosum }(N=15), \text { Sanionia uncinata } \\
(N=15)\end{array}$ \\
\hline $\begin{array}{l}\text { Initial cyanobacteria-moss wet } \\
\text { tundra }(4-6)\end{array}$ & Wet sites on lateral moraine & $\begin{array}{l}\text { S. uncinata }(N=15) \text {, biological soil crust (BSC) } \\
(N=15)\end{array}$ \\
\hline $\begin{array}{l}\text { Epilithic moss-lichen tundra } \\
(7-11)\end{array}$ & Dry sites on acid rocks & $\begin{array}{l}\text { Salix polaris }(N=20), R \text {. lanuginosum }(N=25), \\
\text { Cladonia rangiferina }(N=25), \text { Flavocetraria } \\
\text { nivalis }(N=25)\end{array}$ \\
\hline Polygonal tundra (12-14) & Moderately wet sites on patterned ground & R. lanuginosum $(N=15)$, BSC $(N=15)$ \\
\hline Wet moss tundra (15-20) & Habitats with standing fresh water & $\begin{array}{l}\text { Aulacomnium palustre }(N=5), \text { Bryum } \\
\text { pseudotriquetrum }(N=5), S . \text { uncinata }(N=15) \text {, } \\
\text { Straminergon stramineum }(N=15), \text { Tetraplodon } \\
\text { mnioides }(N=10)\end{array}$ \\
\hline $\begin{array}{l}\text { Ornithocoprophilous tundra under } \\
\text { influence of Alle alle (21-23) }\end{array}$ & Dry rocky debris on slopes & $\begin{array}{l}\text { Cerastium arcticum }(N=15), \text { S. polaris }(N=15), \\
\text { Poa alpina }(N=10), \text { Plagiomnium ellipticum } \\
(N=15), S . \text { uncinata }(N=15), T . \text { mnioides } \\
(N=15)\end{array}$ \\
\hline Flow water moss tundra (24-26) & Habitats with flowing fresh water & $\begin{array}{l}\text { B. pseudotriquetrum sp. }(N=5), S . \text { uncinata } \\
(N=15), S . \text { stramineum }(N=15) \text {, Warnstorfia } \\
\text { sarmentosa }(N=5), \operatorname{BSC}(N=10)\end{array}$ \\
\hline $\begin{array}{l}\text { Snow bed cyanobacteria-moss } \\
\text { tundra }(27-29)\end{array}$ & Damp, loamy habitats on level ground & S. uncinata $(N=15)$, BSC $(N=15)$ \\
\hline $\begin{array}{l}\text { Prostrate shrub lichen tundra } \\
(30-32)\end{array}$ & Dry sites on level to gently sloping ground & $\begin{array}{l}\text { S. polaris }(N=15), S \text {. oppositifolia }(N=15) \text {, } \\
\text { Cetrariella delisei }(N=15)\end{array}$ \\
\hline $\begin{array}{l}\text { Ornithocoprophilous tundra under } \\
\text { influence of Uria lomvia and } \\
\text { Rissa tridactyla (33-35) }\end{array}$ & Rocky debris on slopes & $\begin{array}{l}\text { Cochlearia groenlandica }(N=15), C \text {. arcticum } \\
\quad(N=15), P . \text { alpina }(N=15), \text { Prasiola crispa } \\
(N=15)\end{array}$ \\
\hline
\end{tabular}

Type of tundra modified based on Kuc (1998) and Szymański et al. (2013)

mnioides, and Warnstorfia sarmentosa; lichens: Flavocetraria nivalis, Cetrariella delisei, and Cladonia rangiferina; algae: Prasiola crispa; and the biological soil crust (BSC). At each site within a $25 \mathrm{~m} \times 25 \mathrm{~m}$ square, five replicates per species were randomly collected. Dead material, soil particles, and litter were manually removed from the samples. In addition, topsoil samples (depth of 0-3 cm) in five replicates were collected from each square. Each sample consisted of a mixture of three subsamples. Plant remains and stones were removed from the soil. The total number of soil samples collected was $35 \times 5=175$.

\section{Soil and plant analysis}

Soil and plant samples were dried at $50{ }^{\circ} \mathrm{C}$ until a constant weight was reached. According to Krishna et al. (2003), this temperature is low enough to prevent the loss of mercury. Soil samples were homogenized with a mortar and pestle after the coarse material was removed using a 2-mm sieve. Plant samples were homogenized to a fine powder in an IKA Labortechnik M20 laboratory mill. Dried soil and plant samples (300 mg of dry weight, in triplicate) were digested with $3 \mathrm{~mL}$ of nitric acid (ultra pure, $65 \%$ ) and $2 \mathrm{~mL}$ of perchloric acid (ultra pure, $70 \%$ ) in a CEM Mars 5 microwave oven. Samples were then diluted with deionized water to a total volume of $50 \mathrm{~mL}$, and the soil and plant digests were analyzed for $\mathrm{Fe}, \mathrm{Mn}$, and $\mathrm{Zn}$ using FAAS and $\mathrm{Cd}, \mathrm{Co}, \mathrm{Cr}, \mathrm{Cu}, \mathrm{Ni}$, and $\mathrm{Pb}$ using ETAAS with Graphite Furnace GF3000 (AVANTA PM Atomic Absorption Spectrophotometry from GBC Scientific Equipment). Mercury was analyzed using an AMA 254 Advanced Mercury Analyzer. All elements were assayed against Atomic Absorption Standard Solution from Sigma Chemical Co. and blanks containing the same matrix as the samples and were processed and analyzed as samples. Results of metal concentrations for the plants were calculated on a dry weight basis. The accuracy of the methods applied for the determination of the metal concentrations in plant and soil samples was checked against certified reference materials: moss M2 and M3 (Finnish Forest Research Institute), DC73348 LGC standards of bush branches and leaves, NCS DC73350 poplar leaves, and RTH 907 Dutch Anthropogenic Soil (Wageningen Evaluating Programs for Analytical Laboratories, WEPAL). The coefficient of variance (CV) was calculated for the measured metal concentrations in the reference materials (Online resource 1). 
Statistical analysis

Differences among sampling sites in concentrations of elements in soil, higher plants, mosses, lichens, algae, and the BSC were evaluated by nonparametric ANOVA Kruskal-Wallis analysis. Multiple comparisons of mean ranks for soil, higher plants, mosses, lichens, algae, and the BSC were then calculated.

The matrix of concentrations of 10 metals $(\mathrm{Cd}, \mathrm{Co}, \mathrm{Cr}$, $\mathrm{Cu}, \mathrm{Fe}, \mathrm{Hg}, \mathrm{Mn}, \mathrm{Ni}, \mathrm{Pb}$, and $\mathrm{Zn}$ ) in plant, lichen, algae, and BSC samples from 35 sites after Box-Cox transformation and standardization was subjected to ordination to reveal possible gradients of element levels by means of the principal component and classification analysis (PCCA). Plots of PCCA ordination of the plant, lichen, algae, and BSC samples, and projection of the concentrations of elements on the factor plane give information about similarities between samples and shows correlations between the original variables and the first two factors. (Legendre and Legendre 1998). All calculations were done with the Statistica 10 program Statsoft (2011).

\section{Results}

The ranges of metal concentrations in soil, plant, lichen, algae, and BSC samples are displayed in Tables 2, 3, 4, 5, and 6. The mean concentrations of metals in soil and biota differed significantly (ANOVA, Kruskal-Wallis $P<0.05$ ).

\section{Soil}

Large difference in the carbon percentage (Table 2) in the examined soils depends on the variability of the organic matter content. For example, the geophytic initial dry tundra and initial cyanobacteria-moss wet tundra are growing on a substrate consisting of wet, very fine sand mixed with many rock fragments. However, the epilithic moss-lichen tundra and wet moss tundra are growing on a substrate consisting of dead shoots of mosses on rocky debris (Szymański et al. 2013).

The comparison of metal concentrations observed in the Svalbard soils with pristine soils from the Russian Arctic (in $\mathrm{mg} \mathrm{kg}^{-1}$ : $\mathrm{Cd} 0.2, \mathrm{Cu} 23, \mathrm{~Pb} 9.1, \mathrm{Zn} 29$ ) by Zhulidov et al. (1997) and from much drier tundra soils of the maritime lowland Kaffiöyra in western Spitsbergen (in $\mathrm{mg} \mathrm{kg}^{-1}$ : Cd 0.1, Co 7.4, Cu 23, Fe 29000, Mn 392, Ni 24, $\mathrm{Pb} 12, \mathrm{Zn} 75)$ by Plichta and Kuczyńska (1991) revealed that only the concentration of $\mathrm{Co}$ and $\mathrm{Fe}$ was higher than background concentrations in all types of tundras (Tables 2,3). Multiple comparisons of mean ranks for soils revealed that the two ornithocoprophilous tundras did not differ in concentrations of each of the examined metals

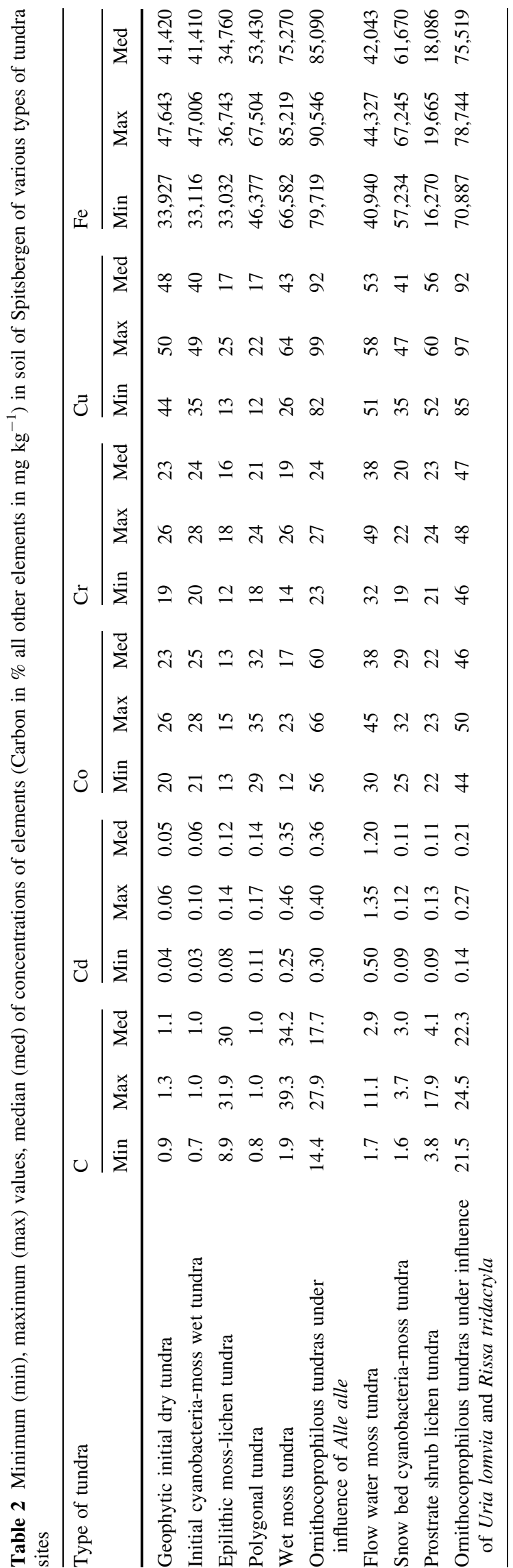


Table 3 Minimum (min), maximum (max) values, median (med) of concentrations of elements $\left(\mathrm{mg} \mathrm{kg}^{-1}\right)$ in soil of Spitsbergen of various types of tundra sites

\begin{tabular}{|c|c|c|c|c|c|c|c|c|c|c|c|c|c|c|c|}
\hline \multirow[t]{2}{*}{ Type of tundra } & \multicolumn{3}{|l|}{$\mathrm{Hg}$} & \multicolumn{3}{|l|}{ Mn } & \multicolumn{3}{|l|}{$\mathrm{Ni}$} & \multicolumn{3}{|l|}{$\mathrm{Pb}$} & \multicolumn{3}{|l|}{$\mathrm{Zn}$} \\
\hline & Min & $\operatorname{Max}$ & Med & Min & Max & Med & Min & $\operatorname{Max}$ & Med & Min & $\operatorname{Max}$ & Med & Min & $\operatorname{Max}$ & Med \\
\hline Geophytic initial dry tundra & 0.009 & 0.01 & 0.01 & 394 & 503 & 450 & 37 & 41 & 39 & 10 & 13 & 11 & 60 & 73 & 65 \\
\hline $\begin{array}{l}\text { Initial cyanobacteria-moss wet } \\
\text { tundra }\end{array}$ & 0.03 & 0.06 & 0.04 & 324 & 501 & 411 & 29 & 35 & 32 & 8 & 11 & 9 & 54 & 81 & 72 \\
\hline Epilithic moss-lichen tundra & 0.05 & 0.54 & 0.25 & 252 & 403 & 316 & 19 & 27 & 23 & 15 & 25 & 19 & 55 & 83 & 70 \\
\hline Polygonal tundra & 0.05 & 0.47 & 0.20 & 531 & 923 & 704 & 41 & 46 & 43 & 20 & 24 & 22 & 72 & 92 & 81 \\
\hline Wet moss tundra & 0.05 & 0.32 & 0.15 & 417 & 1,268 & 886 & 11 & 31 & 23 & 10 & 18 & 14 & 52 & 185 & 120 \\
\hline $\begin{array}{l}\text { Ornithocoprophilous tundras under } \\
\text { influence of Alle alle }\end{array}$ & 0.03 & 0.10 & 0.05 & 1,105 & 1,375 & 1,231 & 75 & 84 & 78 & 34 & 38 & 36 & 213 & 249 & 236 \\
\hline Flow water moss tundra & 0.17 & 0.36 & 0.24 & 201 & 298 & 242 & 53 & 59 & 56 & 34 & 37 & 35 & 229 & 345 & 296 \\
\hline $\begin{array}{l}\text { Snow bed cyanobacteria-moss } \\
\text { tundra }\end{array}$ & 0.03 & 0.04 & 0.04 & 706 & 1,006 & 910 & 39 & 47 & 43 & 10 & 16 & 14 & 71 & 75 & 73 \\
\hline Prostrate shrub lichen tundra & 0.15 & 0.23 & 0.18 & 242 & 643 & 452 & 8 & 15 & 12 & 10 & 14 & 12 & 81 & 96 & 89 \\
\hline $\begin{array}{l}\text { Ornithocoprophilous tundras under } \\
\text { influence of Uria lomvia and } \\
\text { Rissa tridactyla }\end{array}$ & 0.09 & 0.15 & 0.12 & 1,217 & 1,626 & 1,450 & 58 & 62 & 59 & 30 & 44 & 38 & 174 & 184 & 180 \\
\hline
\end{tabular}

Table 4 Minimum (min), maximum (max) values, median (med) of concentrations ( $\mathrm{mg} \mathrm{kg}^{-1}$ ) of $\mathrm{Cd}, \mathrm{Co}, \mathrm{Cr}$, and $\mathrm{Cu}$ in vascular plants, mosses, lichens, and algae and biological soil crust (BSC) of various types of tundra of Spitsbergen

\begin{tabular}{|c|c|c|c|c|c|c|c|c|c|c|c|c|c|}
\hline \multirow[t]{2}{*}{ No } & \multirow[t]{2}{*}{ Species } & \multicolumn{3}{|l|}{$\mathrm{Cd}$} & \multicolumn{3}{|l|}{ Co } & \multicolumn{3}{|l|}{$\mathrm{Cr}$} & \multicolumn{3}{|l|}{$\mathrm{Cu}$} \\
\hline & & Min & Max & Med & Min & Max & Med & Min & Max & Med & Min & Max & Med \\
\hline \multicolumn{14}{|c|}{ Biological soil crust } \\
\hline 1 & BSC & 0.05 & 0.6 & 0.2 & 8.0 & 18 & 13 & 12 & 45 & 27 & 10 & 44 & 25 \\
\hline \multicolumn{14}{|c|}{ Algae } \\
\hline 2 & Prasiola crispa & 1.5 & 1.9 & 1.7 & 1.2 & 1.4 & 1.3 & 3.4 & 4.2 & 3.9 & 27 & 30 & 27 \\
\hline \multicolumn{14}{|c|}{ Lichens } \\
\hline 3 & Flavocetraria nivalis & 0.08 & 0.13 & 0.11 & 0.01 & 0.3 & 0.3 & 0.1 & 0.4 & 0.2 & 0.3 & 1.0 & 0.5 \\
\hline 4 & Cetrariella delisei & 0.07 & 0.1 & 0.09 & 0.1 & 0.3 & 0.14 & 0.4 & 1.4 & 0.8 & 1.1 & 2.0 & 1.4 \\
\hline 5 & Cladonia rangiferina & 0.03 & 0.08 & 0.05 & 0.01 & 0.4 & 0.3 & 0.3 & 0.7 & 0.6 & 0.9 & 1.0 & 1.2 \\
\hline \multicolumn{14}{|c|}{ Mosses } \\
\hline 6 & Aulacomnium palustre & 0.2 & 0.6 & 0.3 & 0.1 & 2.6 & 0.4 & 0.2 & 1.4 & 0.3 & 2.3 & 7.0 & 3.4 \\
\hline 7 & Bryum pseudotriquetrum & 0.2 & 0.4 & 0.3 & 1.4 & 1.9 & 1.6 & 1.5 & 2.4 & 2.0 & 10 & 15 & 12 \\
\hline 8 & Plagiomnium ellipticum & 0.4 & 0.6 & 0.5 & 0.1 & 0.4 & 0.3 & 0.7 & 1.0 & 0.7 & 3.8 & 6.0 & 4.7 \\
\hline 9 & Racomitrium lanuginosum & 0.02 & 0.1 & 0.04 & 0.2 & 11 & 3.0 & 0.2 & 19 & 1.9 & 1.6 & 20 & 3.6 \\
\hline 10 & Sanionia uncinata & 0.03 & 0.9 & 0.1 & 0.3 & 16 & 6.0 & 0.8 & 22 & 6.0 & 2.1 & 29 & 9.0 \\
\hline 11 & Straminergon stramineum & 0.06 & 0.4 & 0.2 & 0.2 & 6.0 & 0.6 & 0.3 & 5.0 & 0.7 & 2.1 & 9.0 & 4.4 \\
\hline 12 & Tetraplodon mnioides & 0.2 & 0.8 & 0.4 & 0.1 & 0.4 & 0.2 & 0.5 & 1.1 & 0.6 & 0.9 & 4.0 & 3.2 \\
\hline 13 & Warnstorfia sarmentosa & 0.1 & 0.3 & 0.2 & 9.0 & 11 & 10 & 14 & 16 & 15 & 16 & 18 & 17 \\
\hline \multicolumn{14}{|c|}{ Vascular plants } \\
\hline 14 & Cerastium alpinum & 0.3 & 1.0 & 0.7 & 0.1 & 0.3 & 0.2 & 0.4 & 0.6 & 0.5 & 1.2 & 5.0 & 3.4 \\
\hline 15 & Cochlearia groenlandica & 0.5 & 0.8 & 0.6 & 0.01 & 0.03 & 0.02 & 0.2 & 0.4 & 0.3 & 1.7 & 2.0 & 1.9 \\
\hline 16 & Poa alpina & 0.02 & 1.1 & 0.1 & 0.1 & 0.2 & 0.1 & 0.3 & 2.0 & 0.8 & 1.7 & 12 & 5.1 \\
\hline 17 & Salix polaris & 0.6 & 2.3 & 1.1 & 0.4 & 3.0 & 0.7 & 0.1 & 1.5 & 0.4 & 4.0 & 7.0 & 5.6 \\
\hline 18 & Saxifraga oppositifolia & 0.02 & 0.2 & 0.1 & 0.1 & 0.4 & 0.3 & 0.4 & 1.1 & 0.8 & 2.4 & 4.0 & 3.0 \\
\hline
\end{tabular}


Table 5 Minimum (min), maximum (max) values, median (med) of concentrations $\left(\mathrm{mg} \mathrm{kg}^{-1}\right.$ ) of $\mathrm{Fe}, \mathrm{Hg}$, and Mn in vascular plants, mosses, lichens, and algae and biological soil crust (BSC) of various types of tundra of Spitsbergen

\begin{tabular}{|c|c|c|c|c|c|c|c|c|c|c|}
\hline \multirow[t]{2}{*}{ No } & \multirow[t]{2}{*}{ Species } & \multicolumn{3}{|l|}{$\mathrm{Fe}$} & \multicolumn{3}{|l|}{$\mathrm{Hg}$} & \multicolumn{3}{|l|}{$\mathrm{Mn}$} \\
\hline & & Min & $\operatorname{Max}$ & Med & Min & $\operatorname{Max}$ & Med & Min & Max & Med \\
\hline \multicolumn{11}{|c|}{ Biological soil crust } \\
\hline 1 & BSC & 12,490 & 32,150 & 22,430 & 0.02 & 0.3 & 0.04 & 142 & 1,520 & 440 \\
\hline \multicolumn{11}{|c|}{ Algae } \\
\hline 2 & Prasiola crispa & 2,400 & 3,420 & 2,990 & 0.17 & 0.19 & 0.18 & 84 & 117 & 95 \\
\hline \multicolumn{11}{|c|}{ Lichens } \\
\hline 3 & Flavocetraria nivalis & 120 & 190 & 160 & 0.03 & 0.05 & 0.04 & 13 & 20 & 16 \\
\hline 4 & Cetrariella delisei & 540 & 1,000 & 750 & 0.06 & 0.09 & 0.08 & 15 & 23 & 20 \\
\hline 5 & Cladonia rangiferina & 410 & 698 & 440 & 0.02 & 0.05 & 0.04 & 8.0 & 12 & 9.0 \\
\hline \multicolumn{11}{|c|}{ Mosses } \\
\hline 6 & Aulacomnium palustre & 140 & 3,410 & 220 & 0.02 & 0.04 & 0.03 & 12 & 120 & 19 \\
\hline 7 & Bryum pseudotriquetrum & 1,290 & 2,160 & 1,720 & 0.02 & 0.03 & 0.02 & 90 & 94 & 92 \\
\hline 8 & Plagiomnium ellipticum & 170 & 770 & 350 & 0.01 & 0.03 & 0.02 & 55 & 92 & 74 \\
\hline 9 & Racomitrium lanuginosum & 320 & 15,910 & 2,590 & 0.03 & 0.10 & 0.04 & 7.0 & 320 & 70 \\
\hline 10 & Sanionia uncinata & 250 & 15,890 & 5,760 & 0.03 & 0.10 & 0.05 & 17 & 850 & 130 \\
\hline 11 & Straminergon stramineum & 110 & 4,840 & 480 & 0.02 & 0.05 & 0.04 & 10 & 440 & 33 \\
\hline 12 & Tetraplodon mnioides & 80 & 520 & 120 & 0.01 & 0.03 & 0.02 & 8.0 & 31 & 18 \\
\hline 13 & Warnstorfia sarmentosa & 13,380 & 13,400 & 13,395 & 0.04 & 0.05 & 0.04 & 420 & 440 & 430 \\
\hline \multicolumn{11}{|c|}{ Vascular plants } \\
\hline 14 & Cerastium alpinum & 114 & 323 & 164 & 0.01 & 0.03 & 0.02 & 28 & 190 & 140 \\
\hline 15 & Cochlearia groenlandica & 115 & 130 & 124 & 0.01 & 0.02 & 0.01 & 27 & 29 & 28 \\
\hline 16 & Poa alpina & 90 & 190 & 120 & 0.01 & 0.02 & 0.01 & 27 & 60 & 40 \\
\hline 17 & Salix polaris & 130 & 660 & 240 & 0.01 & 0.09 & 0.02 & 140 & 280 & 210 \\
\hline 18 & Saxifraga oppositifolia & 150 & 460 & 380 & 0.01 & 0.02 & 0.02 & 16 & 46 & 23 \\
\hline
\end{tabular}

$(P<0.05)$. The high levels of metals found in Spitsbergen sites influenced by birds nesting were reported earlier (Savinov et al. 2003).

\section{Vascular plants}

Of the vascular plants, $P$. alpina contained the highest concentrations of $\mathrm{Cr}, \mathrm{Cu}$, and $\mathrm{Pb}$. S . polaris contained the highest concentrations of $\mathrm{Cd}, \mathrm{Co}, \mathrm{Mn}, \mathrm{Ni}$, and $\mathrm{Zn}$ (Tables 4, 5, 6). Askaer et al. (2008) demonstrated that native graminoid plants of Svalbard in the industrialized area contained phytotoxic concentrations of some metals. In this investigation, only the highest concentrations of $\mathrm{Cu}$ and $\mathrm{Zn}$ in $P$. alpina were higher than average values typical of plants from unpolluted areas (Kabata-Pendias 2001). A comparison of median metal concentrations of vascular plants observed in this study with those reported for the vascular Cassiope tetragona (in $\mathrm{mg} \mathrm{kg}^{-1}$ : Cd 0.2 , Co 1.3 , Cr 1.9, Cu 10, Fe 1556, Hg 0.14, Mn 106, Ni 4.1, Pb 1.6, $\mathrm{Zn} \mathrm{33.5)}$ in the same area 20 years earlier (Drbal et al. 1992) revealed that concentrations of $\mathrm{Co}, \mathrm{Cr}, \mathrm{Cu}, \mathrm{Fe}, \mathrm{Hg}$, $\mathrm{Ni}$, and $\mathrm{Pb}$ had decreased (Tables 4, 5, 6).
Mosses

Median metal concentrations of $R$. lanuginosum observed in this study were also compared with those observed by Drbal et al. (1992) (in mg kg${ }^{-1}$ : Cd 0.2, Co 0.8, Cr 1.4, Cu 3.1, Fe 1205, Hg 0.2, Mn 24, Ni 2.4, Pb 7.3, Zn 11.5) and those observed by Grodzińska and Godzik (1991) (in $\mathrm{mg} \mathrm{kg}^{-1}: \mathrm{Cd} \mathrm{0.3,} \mathrm{Cu} \mathrm{2.3,} \mathrm{Ni} \mathrm{2.4,} \mathrm{Pb} \mathrm{4.9,} \mathrm{Zn} \mathrm{13).} \mathrm{Median}$ metal concentrations of $S$. uncinata were compared with those observed by Grodzińska and Godzik (1991) in the same area (in $\mathrm{mg} \mathrm{kg}^{-1}$ : $\mathrm{Cd}$ 0.6, $\mathrm{Cu} 6.0, \mathrm{Ni} 4.3, \mathrm{~Pb} 7.1, \mathrm{Zn}$ 21). Concentrations of $\mathrm{Cd}, \mathrm{Hg}$, and $\mathrm{Pb}$ have decreased in $R$. lanuginosum, while concentrations of $\mathrm{Co}, \mathrm{Cr}, \mathrm{Cu}, \mathrm{Fe}, \mathrm{Mn}$, and $\mathrm{Ni}$ have increased in this species. Concentrations of $\mathrm{Cu}, \mathrm{Ni}$, and $\mathrm{Zn}$ have increased, and concentrations of $\mathrm{Cd}$ and $\mathrm{Pb}$ have decreased in $S$. uncinata (Tables 4, 5, 6). The lower concentrations of $\mathrm{Hg}$ and $\mathrm{Pb}$ observed in vascular plants, and mosses are in agreement with decreases in $\mathrm{Hg}$ emissions in the past two decades throughout Europe. This finding further emphasizes the susceptibility of the Arctic region to the long-range transport of contaminants from industrialized areas (Pacyna and Keeler 1995; Poikolainen 
Table 6 Minimum (min), maximum (max) values, median (med) of concentrations $\left(\mathrm{mg} \mathrm{kg}^{-1}\right.$ ) of $\mathrm{Ni}, \mathrm{Pb}$, and $\mathrm{Zn}$ in vascular plants, mosses, lichens, and algae and biological soil crust (BSC) of various types of tundra of Spitsbergen

\begin{tabular}{|c|c|c|c|c|c|c|c|c|c|c|}
\hline \multirow[t]{2}{*}{ No } & \multirow[t]{2}{*}{ Species } & \multicolumn{3}{|l|}{$\mathrm{Ni}$} & \multicolumn{3}{|l|}{$\mathrm{Pb}$} & \multicolumn{3}{|l|}{$\mathrm{Zn}$} \\
\hline & & Min & Max & Med & Min & Max & Med & Min & $\operatorname{Max}$ & Med \\
\hline \multicolumn{11}{|c|}{ Biological soil crust } \\
\hline 1 & BSC & 11 & 26 & 20 & 2.4 & 22 & 11 & 32 & 74 & 54 \\
\hline \multicolumn{11}{|c|}{ Algae } \\
\hline 2 & Prasiola crispa & 4.3 & 5.1 & 4.7 & 5.8 & 6.7 & 5.9 & 117 & 130 & 125 \\
\hline \multicolumn{11}{|c|}{ Lichens } \\
\hline 3 & Flavocetraria nivalis & 0.4 & 0.7 & 0.6 & 1.4 & 2.1 & 1.5 & 9.0 & 13 & 10 \\
\hline 4 & Cetrariella delisei & 0.6 & 1.2 & 1.0 & 3.3 & 4.6 & 4.2 & 17 & 25 & 19 \\
\hline 5 & Cladonia rangiferina & 0.4 & 0.8 & 0.6 & 0.6 & 0.9 & 0.7 & 7.0 & 11 & 8.0 \\
\hline \multicolumn{11}{|c|}{ Mosses } \\
\hline 6 & Aulacomnium palustre & 0.01 & 2.2 & 0.1 & 0.3 & 1.9 & 0.6 & 17 & 22 & 20 \\
\hline 7 & Bryum pseudotriquetrum & 0.9 & 2.2 & 1.6 & 2.1 & 2.7 & 2.4 & 35 & 43 & 39 \\
\hline 8 & Plagiomnium ellipticum & 0.5 & 0.7 & 0.5 & 0.2 & 0.7 & 0.4 & 22 & 27 & 24 \\
\hline 9 & Racomitrium lanuginosum & 0.5 & 12 & 4.0 & 0.9 & 23 & 3.0 & 4.0 & 37 & 11 \\
\hline 10 & Sanionia uncinata & 0.01 & 17 & 5.0 & 0.7 & 32 & 3.2 & 15 & 48 & 26 \\
\hline 11 & Straminergon stramineum & 0.02 & 6.1 & 0.3 & 0.3 & 9.4 & 1.1 & 16 & 25 & 22 \\
\hline 12 & Tetraplodon mnioides & 0.01 & 0.9 & 0.8 & 0.4 & 0.9 & 0.6 & 12 & 27 & 24 \\
\hline 13 & Warnstorfia sarmentosa & 12 & 14 & 13 & 7.0 & 9.0 & 8.0 & 35 & 38 & 36 \\
\hline \multicolumn{11}{|c|}{ Vascular plants } \\
\hline 14 & Cerastium alpinum & 0.3 & 0.9 & 0.4 & 0.2 & 0.8 & 0.4 & 36 & 52 & 44 \\
\hline 15 & Cochlearia groenlandica & 0.1 & 0.2 & 0.2 & 1.4 & 1.6 & 1.5 & 34 & 36 & 35 \\
\hline 16 & Poa alpina & 0.01 & 0.8 & 0.4 & 0.4 & 2.6 & 1.0 & 27 & 40 & 38 \\
\hline 17 & Salix polaris & 2.6 & 7.0 & 3.4 & 0.1 & 1.2 & 0.3 & 61 & 180 & 160 \\
\hline 18 & Saxifraga oppositifolia & 0.01 & 1.8 & 1.1 & 0.3 & 0.7 & 0.4 & 13 & 20 & 15 \\
\hline
\end{tabular}

et al. 2004). Multiple comparisons of mean ranks for mosses revealed that there was no significant difference in concentration of metals between species.

\section{Lichens}

A comparison of median metal concentrations of Flavocetraria nivalis with those reported by Drbal et al. (1992) for this species (in mg kg ${ }^{-1}: \mathrm{Cd} \mathrm{0.1,} \mathrm{Co}<0.5, \mathrm{Cr}$ 0.9, $\mathrm{Cu}$ 1.4, Fe 237, Hg 0.1, Mn 14.9, Ni 1.6, Pb 4.9, Zn 13.4) revealed that concentrations of $\mathrm{Cr}, \mathrm{Cu}, \mathrm{Fe}, \mathrm{Hg}, \mathrm{Ni}$, $\mathrm{Pb}$, and $\mathrm{Zn}$ have decreased (Tables 4, 5, 6). Multiple comparisons of mean ranks for lichens revealed that $C$. delisei contained significantly higher concentrations of $\mathrm{Mn}, \mathrm{Pb}$, and $\mathrm{Zn}(P<0.05)$ than $C$. rangiferina and significantly higher concentrations of $\mathrm{Cr}, \mathrm{Cu}$, and $\mathrm{Fe}$ $(P<0.05)$ than $F$. nivalis. The comparison of the metal concentrations between mosses and lichens by the MannWhitney $\mathrm{U}$ Test $(P<0.05)$ revealed that mosses contained significantly higher concentrations of $\mathrm{Cd}, \mathrm{Co}, \mathrm{Cr}$, $\mathrm{Cu}, \mathrm{Fe}, \mathrm{Mn}$, and $\mathrm{Zn}$. There was no difference in concentration of $\mathrm{Hg}, \mathrm{Ni}$, and $\mathrm{Pb}$.
Algae

Compared with metal concentrations $\left(\mathrm{mg} \mathrm{kg}^{-1}\right)$ in algae from Spitsbergen given by Drbal et al. (1992), the highest concentrations of $\mathrm{Cd}$ (0.2), $\mathrm{Co}$ (1.3), $\mathrm{Cr}$ (1.1), $\mathrm{Cu}$ (5.5), Fe (255), $\mathrm{Hg}$ (0.06), Mn (10), Ni (3.3), Pb (0.5), and Zn (12) in all $P$. crispa samples were higher than those observed 20 years ago (Tables $4,5,6$ ).

Biological soil crust

As we did not find any publications containing data on metal concentrations in the BSC in Arctic regions, we compared our results to the average metal concentrations $\left(\mathrm{mg} \mathrm{kg}^{-1}\right)$ in BSC from Hohe Tauern, Austria given by Peer et al. (2010). The BSC from Spitsbergen contained higher concentrations of $\mathrm{Cd}(0.41), \mathrm{Cu}(11.5)$, and $\mathrm{Ni}$ (22.4); and lower concentrations of $\mathrm{Pb}$ (107) and $\mathrm{Zn}$ (62) than those reported in Peer et al. (2010).

The ratio of metal concentration in biota to metal concentration in soil (Fig. 2) showed that the accumulation of all metals (except $\mathrm{Hg}$ and $\mathrm{Zn}$ ) was highest in the BSC. The 

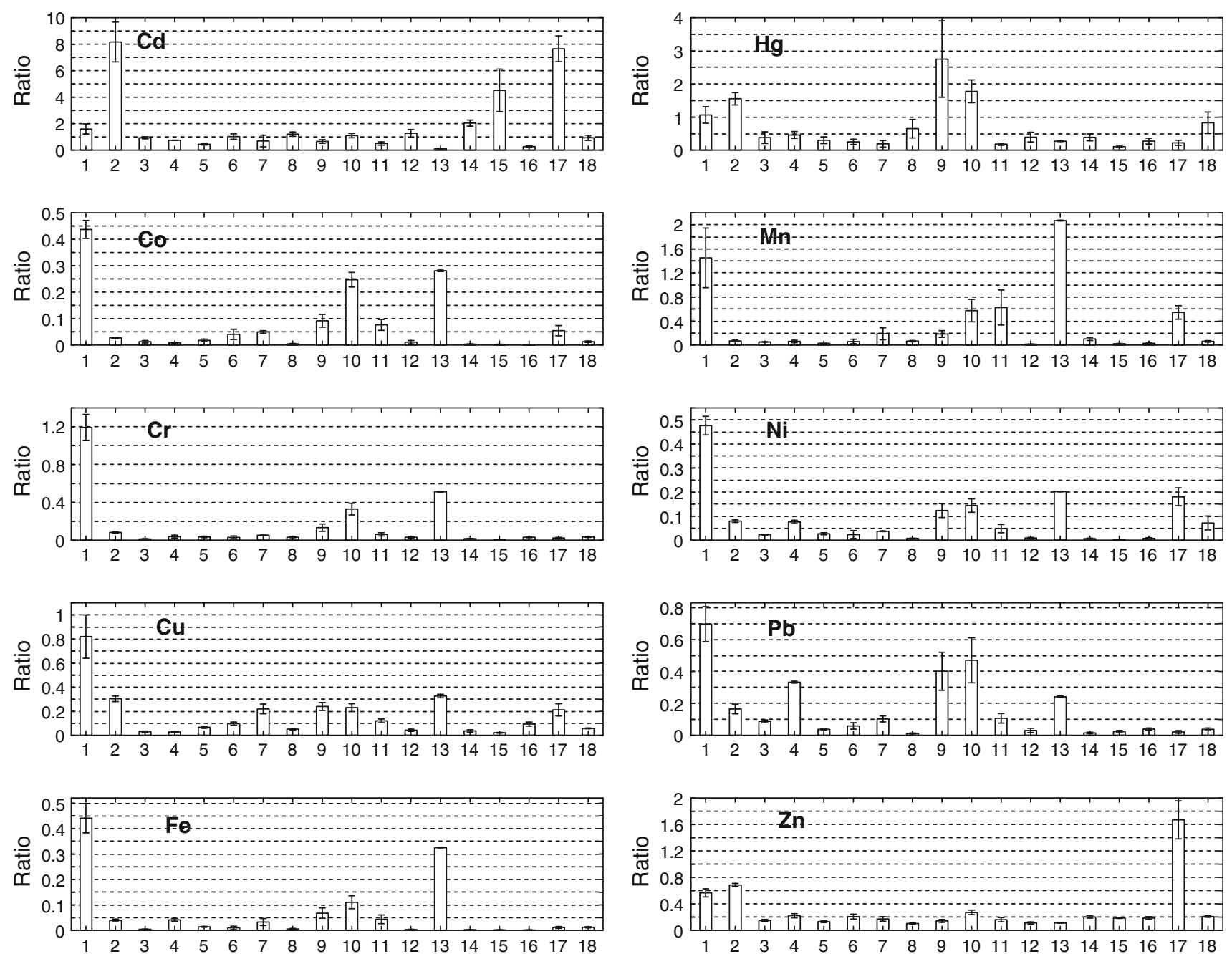

Fig. 2 Ratio for concentration of metals in biota divided by concentration of metals in soil (numbers of BSC, algae, vascular plants, mosses, lichens in the Tables 4, 5, and 6), bar: mean, I: standard error

ratio for $\mathrm{Hg}$ was highest in $\mathrm{R}$. lanuginosum and for $\mathrm{Zn}$ was S. polaris (Fig. 2).

\section{Discussion}

Multiple comparisons of mean ranks for all BSC, algae, lichens, mosses, and higher plant samples revealed that $P$. crispa contained significantly higher $(P<0.05)$ concentrations of $\mathrm{Cu}$ than all other samples, except for the BSC, $S$. uncinata, and $R$. lanuginosum, while the BSC contained significantly higher $(P<0.01)$ concentrations of Co and $\mathrm{Ni}$ than all other samples, except for $P$. crispa. These results are in contrast to Drbal et al. (1992) who found lower metal concentrations in algae than in higher plants.

Our results are supported by the PCCA ordination (Fig. 3). The first principal component discriminates between all BSC samples from initial cyanobacteria-moss wet tundra, polygonal tundra, snow bed cyanobacteriamoss tundra, and flow water moss tundra; mosses: $R$. lanuginosum of geophytic initial dry tundra and polygonal tundra; S. uncinata of geophytic initial dry tundra, initial cyanobacteria-moss wet tundra, snow bed cyanobacteriamoss tundra, and flow water moss tundra; W. sarmentosa of flow water moss tundra; S. stramineum of flow water moss tundra (negative scores); and all moss species, lichens, and higher plants of other sampling sites (positive scores). The second principal component is correlated (positive scores) with all $P$. crispa and $S$. polaris. The projection of the variables on the factor plane showed that the BSC, $R$. $l a$ nuginosum, S. uncinata, S. stramineum, and W. sarmentosa with negative scores of factor one were highly correlated with the highest concentrations of $\mathrm{Co}, \mathrm{Cr}, \mathrm{Cu}, \mathrm{Fe}, \mathrm{Hg}, \mathrm{Mn}$, $\mathrm{Ni}$, and $\mathrm{Pb}$ in their tissues. P. crispa and $S$. polaris from all sites with positive scores of factor two were correlated with the highest concentrations of $\mathrm{Cd}$ and $\mathrm{Zn}$. The highest 


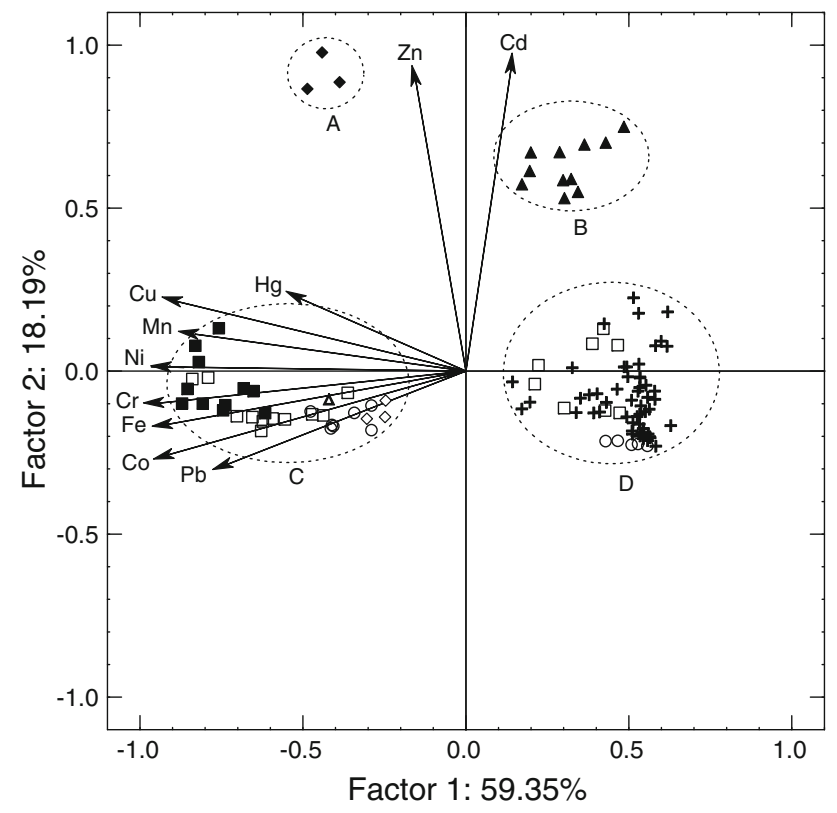

Fig. 3 Ordination plot of higher plants, mosses, lichens, algae, and $\mathrm{BSC}$ based on concentrations of the 10 metals $\mathrm{Cd}, \mathrm{Co}, \mathrm{Cr}, \mathrm{Cu}, \mathrm{Fe}, \mathrm{Hg}$, $\mathrm{Mn}, \mathrm{Ni}, \mathrm{Pb}$, and $\mathrm{Zn}$ and projection of metal concentrations on the component plane. Filled square biological soil crust, open square $S$. uncinata, open circle $R$. lanuginosum, open triangle $W$. sarmentosa, open diamonds $S$. stramineum, filled diamonds $P$. crispa, filled triangle $S$. polaris, plus sign remaining species

concentrations of metals were found in the BSC, $R$. lanuginosum, $S$. uncinata, $S$. stramineum, and W. sarmentosa from types of tundra which, except for geophytic initial dry tundra, receive water from melting ice or snow. Spring runoff water alimenting these tundras contains elevated concentrations of metals, and soil-water interactions in tundra soils are a potential source of nutrients for surrounding ecosystems (Elberling et al. 2007; Tye and Heaton 2007). Additionally, water from melting glaciers containing an additional portion of metals deposited from the air should be taken into account (Drbal et al. 1992). Of the moss species examined, $S$. uncinata appeared to be an efficient bioindicator of metal pollution (Samecka-Cymerman et al. 2011). The reason for the elevated concentrations of metals in $R$. lanuginosum and $S$. uncinata from the geophytic initial dry tundra became clearer when we consider elevation. Although the difference in altitude between this tundra site and the other sites was only $26 \mathrm{~m}$, $S$. uncinata and $R$. lanuginosum at this site were likely more exposed to pollution transported by wind. Svalbard is located very far from major sources of atmospheric pollution. However, some long-range transport of pollutants has been reported, and atmospheric deposition is a significant source of metals in Arctic ecosystems (Bashkin and Howarth 2002; Birks et al. 2004; Samecka-Cymerman et al. 2011). The supply of sea salts and trace metals via precipitation also appears to contribute to high metal concentrations observed in Spitsbergen biota (Bard 1999; Bashkin and Howarth 2002).

The high concentrations of metals in the BSC support the suggestion by Beraldi-Campesi et al. (2009) that the BSC plays a role in soil fertility and influences the metal budgets of associated soil and biota. These authors observed that soils underneath the crusts showed depletion of non-biogenic elements. Peer et al. (2010) confirmed that the BSC acts as captors for atmogenic heavy metals. The very high concentrations of metals in the indicator species $P$. crispa for soils fertilized with wastes (Olech 1996) may be connected with the fact that in this investigation, P. crispa grew only in ornithocoprophilous tundra in the vicinity of colonies of Uria lomvia and Rissa tridactyla feeding on marine fishes and molluscs. As these birds breed on land, they transport contaminants (among them a significant amount of trace metals) to coastal areas in levels that may affect those ecosystems (Grodzińska and Godzik 1991; Dowdall et al. 2005). Seabirds act as a vector for the transport of metals between the marine and terrestrial ecosystems (Headley 1996). Their excretions are the most probable sources of metals to $P$. crispa that grow in the vicinity of bird colonies (Bargagli et al. 1998). It is important to note, however, that other species growing under the influence of bird colonies, $C$. groenlandica and $C$. arcticum, contained low concentrations of metals. The Mann-Whitney U test comparing the concentration of metals in $S$. polaris indicated that this species collected from both epilithic moss-lichen tundra and prostrate shrub lichen tundra contained significantly higher concentrations of $\mathrm{Zn}$ and $\mathrm{Cu}(P<0.05)$ than $S$. polaris collected from ornithocoprophilous tundra. This phenomenon may be attributed to metal dilution by higher biomass production. In areas characterized by low primary production and very slow decomposition processes, the availability of soil nutrients is almost negligible. However, additional sources of macroelements, by the presence of numerous seabirds whose excrements fertilize the area around their breeding colonies, affect development of the specific plant communities of ornithocoprophilous tundra receiving extremely high loadings of nitrogen and phosphorus (Olech et al. 2011). According to Baddeley et al. (1994) S. polaris in particular was very responsive to nitrogen and phosphorus inputs, showing an increase in biomass. Concentration $\left(\mathrm{mg} \mathrm{kg}^{-1}\right)$ of nitrogen and phosphorus in soil of ornithocoprophilous tundra was as high as $9,000-18,100$ and 600-700, respectively, and in S. polaris was as high as 30,000 and 5,630, respectively. In comparison, nitrogen and phosphorus concentrations $\left(\mathrm{mg} \mathrm{kg}^{-1}\right)$ in soil of initial tundra were 300-390 and 300-370, respectively. Rate et al. (2004) reported that plant uptake of all elements increased with increasing biosolid application, suggesting that the dilution effect by increased plant biomass was responsible for erratic metal concentrations. 


\section{Conclusions}

In this study, mosses were better bioindicators of $\mathrm{Cd}, \mathrm{Co}$, $\mathrm{Cr}, \mathrm{Cu}, \mathrm{Fe}, \mathrm{Mn}$, and $\mathrm{Zn}$ than lichens. PCCA analysis revealed that the BSC, $R$. lanuginosum, $S$. uncinata, and $S$. stramineum accumulated the highest concentrations of Co, $\mathrm{Cr}, \mathrm{Cu}, \mathrm{Fe}, \mathrm{Hg}, \mathrm{Mn}, \mathrm{Ni}$, and $\mathrm{Pb}$ in their tissues growing in polygonal tundra, initial cyanobacteria-moss wet tundra, snow bed cyanobacteria-moss tundra, and flow water moss tundra alimented by melting ice or snow. This implicates the probability that metal contaminants observed to bioaccumulate in these species originate from atmospheric deposits; therefore, a high degree of metal accumulation can be linked to greater wetness of habitats. P. crispa and $S$. polaris were the best accumulators of $\mathrm{Cd}$ and $\mathrm{Zn}$. Mosses are known to be bioindicators in Spitsbergen, as they accumulate significantly higher concentrations of metals than lichens. These results therefore suggest that the observed higher concentrations of $\mathrm{Cu}$ in mosses and lower concentrations of $\mathrm{Hg}$ in mosses, lichens, and vascular plants in 2011, compared with values observed in 1992, are associated with changes in the atmospheric deposition of contaminants over Spitsbergen, likely because of changes in the long-distance transport of anthropogenic emissions from industrialized areas.

Acknowledgments This research was supported by the Polish National Science Centre, Grant no. N N304 410139, 2011-2013. G. Skrzypek was supported by Future Fellowship from Australian Research Council.

Open Access This article is distributed under the terms of the Creative Commons Attribution License which permits any use, distribution, and reproduction in any medium, provided the original author(s) and the source are credited.

\section{References}

Askaer L, Schmidt LB, Elberling B, Asmund G, Jónsdóttir IS (2008) Environmental impact on an Arctic soil-plant system resulting from metals released from coal mine waste in Svalbard $\left(78^{\circ} \mathrm{N}\right)$. Water Air Soil Pollut 195:99-114

Baddeley JA, Woodin SJ, Alexander IJ (1994) Effects of increased nitrogen and phosphorus availability on the photosynthesis and nutrient relations of three arctic dwarf shrubs from Svalbard. Funct Ecol 8:676-685

Bard SM (1999) Global transport of anthropogenic contaminants and the consequences for the Arctic marine ecosystem. Mar Pollut Bull 38:356-379

Bargagli R, Sanchez-Hernandez JC, Martella L, Monaci F (1998) Mercury, cadmium and lead accumulation in Antarctic mosses growing along nutrient and moisture gradients. Polar Biol 19:316-322

Bashkin VN, Howarth RW (2002) Modern biogeochemistry. Kluwer Academic Publishers, Dordrecht

Beraldi-Campesi H, Hartnett HE, Anbar A, Gordon GW, Garciapichel F (2009) Effect of BSC on soil elemental concentrations: implications for biogeochemistry and as traceable biosignatures of ancient life on land. Geobiology 7:348-359

Birks HJB, Jones VJ, Rose NL (2004) Recent environmental change and atmospheric contamination on Svalbard as recorded in lake sediments: an introduction. J Paleolimnol 31:403-410

Davey MC (1997) Effects of short-term dehydration and rehydration on photosynthesis and respiration by Antarctic bryophytes. Environ Exp Bot 37:187-198

Dowdall M, Gwynn JP, Gabrielsen GW (2005) Assessment of elevated radionuclide levels in soils associated with an avian colony in a High Arctic environment. Soil Sediment Contam 14:1-11

Drbal K, Elster J, Komárek J (1992) Heavy metals in water, ice and biological material from Spitsbergen, Svalbard. Polar Res 11:99-101

Elberling B, Søndergaard J, Jensen LA, Schmidt LB, Hansen BU, Asmund $\mathrm{G}$, Zunić TB, Hollesen $\mathrm{J}$, Hanson $\mathrm{S}$, Jansson PE, Friborg T (2007) Arctic vegetation damage by winter-generated coal mining pollution released upon thawing. Environ Sci Technol 41:2407-2413

Grodzińska K, Godzik B (1991) Heavy metals and sulphur in mosses from Southern Spitsbergen. Polar Res 9:133-140

Gulińska J, Rachlewicz G, Szczuciński W, Barałkiewicz D, Kózka M, Bulska E, Burzyk M (2003) Soil contamination in high Arctic areas of human impact, central Spitsbergen, Svalbard. Pol J Environ Stud 12:701-707

Headley AD (1996) Heavy metal concentrations in peat profiles from the high Arctic. Sci Total Environ 177:105-111

Heintzenberg J, Hansson H-C, Lannefors H (1981) The chemical composition of arctic haze at Ny-Alesund, Spitsbergen. Tellus 33(2):162-171

Heintzenberg J, Strom J, Ogren JA, Fimpet HP (1991) Vertical profiles of aerosol properties in the summer troposphere of central Europe, Scandinavia and the Svalbard region. Atmos Environ A 25:621-627

Hoshino T, Tojo M, Okada G, Kanda H, Ohgiya S, Ishizaki K (1999) A filamentous fungus, Pythium ultimum Trow var. ultimum, isolated from moribund moss colonies from Svalbard, northern islands of Norway. Polar Biosci 12:68-75

Kabata-Pendias A (2001) Trace elements in soils and plants. CRC Press, Boca Raton

Krishna MVB, Karunasagar D, Arunachalam J (2003) Study of mercury pollution near a thermometer factory using lichens and mosses. Environ Pollut 124:357-360

Kuc M (1998) Environs of the Polish Polar Station (Isbjörnhamna, North Hornsund, Spitsbergen) as survey in 1958 by vegetation mapping and related methods. In: Głowacki P, Bednarek J (eds) Polish polar studies. Twenty-fourth international polar symposium. Institute of Geophysics of the Polish Academy of Sciences, Warszawa, pp 141-157

Legendre P, Legendre L (1998) Numerical ecology, second English ed. Developments in environmental modelling. Elsevier, Amsterdam

Liu X, Zhao S, Sun L, Yin X, Xie Z, Honghao L, Wang Y (2006) P and trace metal contents in biomaterials, soils, sediments and plants in colony of red-footed booby (Sula sula) in the Dongdao Island of South China Sea. Chemosphere 65:707-715

Olech M (1996) Human impact on terrestrial ecosystems in west Antarctica. NIPR Symp Polar Biol 9:299-306

Olech M, Węgrzyn M, Lisowska M, Słaby A, Angiel P (2011) Contemporary changes in vegetation of polar regions. Papers Glob Change IGBP 18:35-51

Pacyna JM, Keeler GJ (1995) Sources of mercury in the Arctic. Water Air Soil Poll 80:621-632

Peer T, Türk R, Gruber JP, Tschaikner A (2010) Species composition and pedological characteristics of biological soil crusts in a high alpine ecosystem, Hohe Tauern, Austria. Eco Mont J Prot Mt Areas Res Manag 2:23-30 
Plichta W, Kuczyńska I (1991) Metal contents in soils of Kaffiöyra, Spitsbergen. Pol. Polar Res 12(2):183-193

Poikolainen J, Kubin E, Piispanen J, Karhu J (2004) Atmospheric heavy metal deposition in Finland during 1985-2000 using mosses as bioindicators. Sci Total Environ 318:171-185

Rate AW, Lee KM, French PA (2004) French Application of biosolids in mineral sands mine rehabilitation: use of stockpiled topsoil decreases trace element uptake by plants. Bioresour Technol 91:223-231

Samecka-Cymerman A, Wojtuń B, Kolon K, Kempers AJ (2011) Sanionia uncinata (Hedw.) loeske as bioindicator of metal pollution in polar regions. Polar Biol 34:381-388

Savinov VM, Gabrielsen GW, Savinova TN (2003) Cadmium, zinc, copper, arsenic, selenium and mercury in seabirds from the Barents Sea: levels, inter-specific and geographical differences. Sci Total Environ 306:133-158

Simões JC, Zagorodnov VC (2001) The record of anthropogenic pollution in snow and ice in Svalbard, Norway. Atmos Environ 35:403-413

Smith AJE (ed) (1982) Bryophyte ecology. Chapman and Hall Ltd., New York
StatSoft Inc (2011) STATISTICA (data analysis software system), version 10. http://www.statsoft.com

Szymański W, Skiba S, Wojtuń B (2013) Distribution, genesis, and properties of Arctic soils: a case study from the Fuglebekken catchment, Spitsbergen. Pol Polar Res 34:3. doi:10.2478/popore2013-0017

Tye AM, Heaton THE (2007) Chemical and isotopic characteristics of weathering and nitrogen release in non-glacial drainage waters on Arctic tundra. Geochim Cosmochim Acta 71(17):4188-4205

Walker DA, Raynolds M K, Daniëls FJA, Einarsson E, Elvebakk A, Gould WA, Katenin A E, Kholod SS, Markon CJ, Melnikov ES, Moskalenko MNG, Talbot SS, Yurtsev BA, CAVM Team (2005) The Circumpolar Arctic Vegetation Map. J Veg Sci $16: 267-282$

Xie Z, Sun L, Blum JD, Huang Y, He W (2006) Summertime aerosol chemical components in the marine boundary layer of the Arctic Ocean. J Geophys Res 111, D10, 309: 1-11

Zhulidov AV, Headley JV, Robarts RD, Nikanorov AM, Ischenko AA, Champ MA (1997) Concentrations of $\mathrm{Cd}, \mathrm{Pb}, \mathrm{Zn}$ and $\mathrm{Cu}$ in pristine wetlands of the Russian Arctic. Mar Pollut Bull $35: 242-251$ 